\title{
LA BATALLA DEL ROMANCERO: LOPE DE VEGA, LOS ROMANCES MORISCOS Y LA VILLANA DE GETAFE
}

\section{Antonio SÁnchez Jiménez (Université de Neuchâtel)}

Cita Recomendada: Antonio Sánchez Jiménez, «La batalla del romancero: Lope de Vega, los romances moriscos y La villana de Getafe», Anuario Lope de Vega. Texto, literatura, cultura, XX (2014), pp. 159-186.

DOI: <http://dx.doi.org/10.5565/rev/anuariolopedevega.89>

\section{RESUMEN}

Este trabajo estudia hasta qué punto se implicó Lope de Vega en las polémicas sobre el romancero morisco, y evalúa las posibles connotaciones políticas que han propuesto críticos como María Soledad Carrasco Urgoiti, Francisco Márquez Villanueva y Barbara Fuchs. Centrándonos en un corpus de romances satíricos y una comedia (La villana de Getafe), rechazamos la lectura política de estos textos para proponer una basada en los intereses literarios del autor.

Palabras clave: Lope de Vega; romancero morisco; La villana de Getafe; lecturas políticas.

\section{Abstract}

This article examines to what extent Lope de Vega was involved in the controversy surrounding the romancero morisco, and evaluates the possible political connotations that critics such as María Soledad Carrasco Urgoiti, Francisco Márquez Villanueva and Barbara Fuchs have found in the romances. Analyzing a corpus of satirical romances and a comedia (La villana de Getafe), we reject those political interpretations in favor of a reading closer to Lope's literary interests.

KeYwords: Lope de Vega; romancero morisco; La villana de Getafe; political readings. 
$\mathrm{U}$

no de los aspectos más intrigantes del romancero nuevo son las sátiras y parodias contra el romancero morisco que comenzaron a imprimirse a partir de 1592. Son textos como «Ensíllenme el asno rucio» y «Triste pisa y afligido» (Góngora, Romances, I, núms. 18 y 22), ${ }^{1}$ varios romances anónimos y los poemas que Gabriel Lasso de la Vega publicó en el Manojuelo de romances. La crítica ha prestado atención a estos textos desde que Agustín Durán los compilara en su Romancero de romances moriscos [1828:223-240] y en el Romancero general [1849:128-136], ${ }^{2}$ que se ha convertido en una especie de Vulgata del subgénero. Desde entonces las interpretaciones han menudeado, y algunas de ellas han sacado a relucir el nombre de poetas célebres como Pedro Liñán de Riaza o Lope de Vega.

El presente trabajo analiza el grado de implicación de Lope en las polémicas sobre el romancero morisco y evalúa sus posibles connotaciones políticas. Para ello, examinamos brevemente los textos con el fin de contextualizar los pasajes relevantes para nuestro estudio. Luego nos centramos en las opiniones que los críticos han expresado al respecto, desde la psicológica de Emilio Orozco Díaz a las políticas de María Soledad Carrasco Urgoiti, Francisco Márquez Villanueva y Barbara Fuchs. Tras ello examinamos su validez y calibramos si se pueden compaginar con una lectura más centrada en los intereses literarios del Fénix. Lo comprobamos con un corpus que comprende algunos romances satíricos («iAh, mis señores poetas", «Háganme vuestras mercedes», «Tanta Zaida y Adalifa» y «Toquen apriesa a rebato»), una respuesta a los mismos («¿Por qué, señores poetas?»), los dos romances de la polémica sobre el Tajo ("A vos digo, señor Tajo» y «Bien parece, padre Tajo») y, finalmente, una comedia lopesca, La villana de Getafe.

Los romances que nos interesan fueron impresos durante los años noventa en las diversas flores que luego se recogieron en el Romancero general. Muchos salieron juntos, pues «iAh, mis señores poetas!» y «Tanta Zaida y Adalifa» aparecieron seguidos en la Cuarta y quinta parte de flor de romances (1592), acompañados de su respuesta, «¿Por qué, señores poetas?». En cuanto a «Háganme vuestras mercedes» y «Toquen apriesa a rebato», aparecieron en el manuscrito Cancionero de Gabriel de Peralta (BNM, Ms. 4072) y la Séptima parte de flor de varios romances nuevos

1 Citamos los romances de Góngora por la edición de Antonio Carreira [1998], aunque consultamos también la de Antonio Carreño [2000].

2 Modernamente, los edita Ruiz Lagos [2001:159-212]. 
(1595), respectivamente. ${ }^{3}$ De los dos romances del Tajo, el de Góngora está en el manuscrito Chacón, y el segundo en el Ramillete de flores (1593), aunque, dado que se ha atribuido a Lope, lo citaremos según la edición de Antonio Sánchez Jiménez [en prensa].

Precisamente un romance de Lope es el blanco de «Háganme vuestras mercedes», pues este poema ridiculiza «Mira, Zaide, que te aviso» enfatizando su éxito entre todas las capas sociales. Entre ellas incluye un gremio asociado con los moriscos, los «buñoleros», que, afirma, «son de su linaje» (vv. 25-26), en referencia al moro que protagoniza el poema satirizado. Tras proseguir con la lista de profesiones, el romance acaba aludiendo al destierro del autor de «Mira, Zaide», es decir, Lope. Por su parte, «Toquen apriesa a rebato» comienza citando una lista de romances moris$\cos$ - y alguno no morisco- atribuidos a Lope. Luego introduce el personaje de una dama que, informada de quién es el autor de esos poemas, comienza una diatriba contra el Fénix. En ella acusa al poeta madrileño de tener sangre morisca:

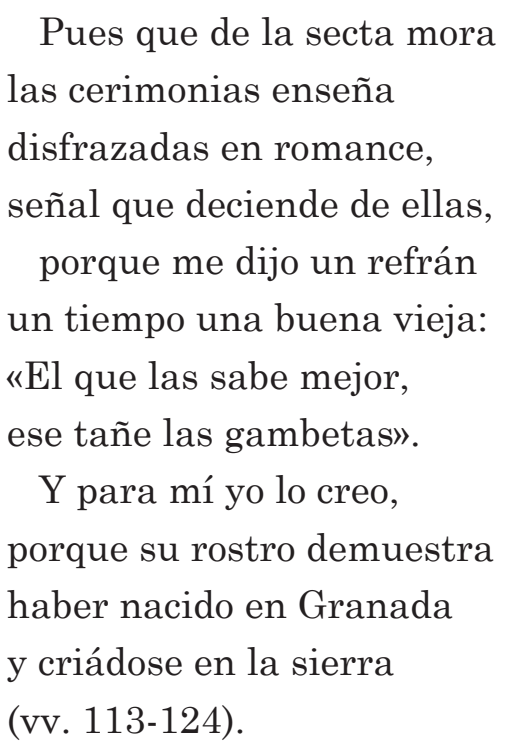

Como señalan Chantal Colonge [1969-1970:144] y Márquez Villanueva [1988:317-318], la acusación tiene un aire de broma que se percibe al final del

3 Citamos tres de estos poemas según la edición de Sánchez Jiménez de los Romances de Lope [en prensa]: «iAh, mis señores poetas», «Toquen apriesa a rebato» y «Háganme vuestras mercedes» —atribuidos con poco fundamento a Lope- - «¿Por qué, señores poetas?», que podría ser lopesco. En cuanto a «Tanta Zaida y Adalifa» y «Háganme vuestras mercedes», los citamos según el Romancero general (1600). 
poema. Y es que la última cuarteta desvela quién enunciaba las quejas: un estudiante cansado de los aires de grandeza de un poeta de géneros bajos:

\author{
enfadado de poetas \\ que quieren por un romance \\ ser dioses acá en la tierra \\ (vv. 142-144).
}

Este colofón hace verosímil que el romance fuera escrito en un ambiente de rivalidades literarias, $\mathrm{y}$ tal vez incluso que fuera obra de un poeta conocido por el Fénix.

En cualquier caso, «Tanta Zaida y Adalifa» $\mathrm{y}$ "Ah, mis señores poetas» insisten en asociar la convención literaria del romancero morisco con la fe islámica. El primero comienza expresando cansancio ante la temática morisca y poniendo de relieve sus tópicos, como los brillantes ropajes y los juegos de cañas. También reprende a los poetas por traducir a las musas al «arábigo», e incluso por haber renegado:

\footnotetext{
Renegaron de su ley los romancistas de España, y ofrecieron a Mahoma las primicias de sus gracias.

Dejaron los graves hechos de su vencedora patria y mendigan de la ajena invenciones y patrañas (Romancero general, f. 52v).
}

La acusación viene acompañada de una asociación de la "vencedora patria» con la reconquista cristiana y con la verdad, y de los moros con el extranjero y la mentira. Prosigue lamentando el olvido en que yacen los antiguos romances y cantares, aunque curiosamente no solamente propone como protagonistas a los adalides de la reconquista cristiana, pues incluye entre los héroes que celebra a Mudarra. Además, le pide a Apolo — no al Dios cristiano— que maldiga a los «poetas moriscos» y que les dé una poética zurra (f. $52 \mathrm{v}$ ). Se trata, pues, de un romance que presenta a veces una posición muy agresiva contra el romancero morisco pero que también reconoce el valor de héroes cristianos nuevos (Mudarra), y que, 
en todo caso, coloca su diatriba en un ámbito puramente literario: el del reino de Apolo.

«iAh, mis señores poetas!» (Góngora, Romances, III, núm. 135) retoma el tema religioso con menos tono de chanza literaria. Comienza apelando a los autores de romances a despojarse de sus máscaras moriscas y a adoptar temas patrios, simbolizados por una danza, la "gallarda española» (no las zambras moriscas) y por dos caballeros, «don Rodrigo y don Pedro» (no los Zaides y Audallas, vv. 9-14). A continuación, el autor les pregunta a los poetas a quienes apela sobre su idea de la nación española:

\footnotetext{
Y, para ablar más claro, ansí tengan buenas pascuas, si a venido a su noticia que ay christianos en España (vv. 25-28).
}

Además, relaciona ese concepto con la opinión extranjera, y en concreto la de los herejes. Con tanto énfasis en lo moro, arguye, los romancistas les están dando a estos maliciosos extranjeros material para construir sus injurias contra España:

\footnotetext{
¿Quieren que diga el erege

de nuestra fe sacrosanta que de sus nonbres de pila se le sig[u]e alguna ynfamia? (vv. 29-32).
}

El autor de «iAh, mis señores poetas!» concluye que los romances moriscos cubren a España de «mill falsos testimonios» (v. 43), por lo que conviene dejar los temas moros y volver a cantar a los héroes cristianos de la Reconquista. Esta vez en la lista no aparece Mudarra, pero sí el Cid, y los héroes de «la conquista de Granada» (v. 84). Es más, incluso los temas clásicos o extranjeros serían mejores que los que proporcionan esas «chusmas morismas» (v. 85), afirma el autor.

Se trata del romance satírico más agresivo del grupo, pero aparece impreso seguido de su «amusante réponse» (Colonge 1969-1970:142), “¡Por qué, señores poetas?», lo que sugiere que los dos pudieron haber sido escritos para una misma ocasión académica. En cualquier caso, «¿Por qué, señores poetas?» comienza con una apelación a los del gremio para volver por su fama y reaccionar contra el 
«Judas» que ataca a su propio «cuerpo» (Vega Carpio, Romances, vv. 9-12). Este énfasis en una disputa interna refuerza el aire académico del intercambio, que también recuerda el hecho de que el autor parezca conocer a su adversario, a quien identifica como «un ninfo del Leteo» (v. 15), es decir, un andaluz. Tras este exordio el poeta responde a las críticas del romance anterior, comenzando por afirmar la españolidad de los moros granadinos:

Si es español don Rodrigo, español fue el fuerte Audalla.

$[\ldots]$

Si una gallarda española quiere bailar doña Juana, las zambras también lo son, pues es España Granada (vv. 21-28).

Es decir, el poeta se mantiene aquí "sur ce même terrain de l'orgueil national» (Colonge 1969-1970:142) que había invocado la sátira a la que contesta. Luego prosigue subrayando la gloria que se le sigue a la nación española por haber derrotado a los moros. De hecho, señala, cantar a los enemigos no hace sino aumentar la prez de los vencedores (vv. 45-48). Además, añade que los héroes cristianos que proponía el autor de «Ah, mis señores poetas!» resultan demasiado severos para hacerles bailar «compuestos / entre el amor y damas» (vv. 54-55). Por ello parece más apropiado cantar esos temas bajo nombres moriscos, pues estos «siempre de amor trataban» (v. 60). Finalmente, el autor de «¡Por qué, señores poetas?» concluye, como «Tanta Zaida y Adalifa», pidiendo la maldición de Apolo para el poeta rival, y lo hace utilizando imágenes tan violentas como las del poema anterior. Estamos, pues, ante un tiroteo poético con un tono generalmente ligero, entre poetas que se conocen y que entienden su enfrentamiento como un encuentro literario. Como veremos luego, los romances del Tajo se mantienen en esa tónica.

En cuanto al otro texto de nuestro corpus, La villana de Getafe, es de índole muy diferente: es una comedia de capa y espada con elementos villanescos, notablemente en la primera jornada, que transcurre en Getafe. ${ }^{4}$ También destacan en la

4 José María Díez Borque ha subrayado al respecto la función estructurante de la oposición corte / aldea [1999:33]. 
obra varios elementos satíricos sobre la vida de la corte: ${ }^{5}$ coches (Dixon 1984), modales, lujosas ropas, murmuración. Los protagonistas son el caballero andaluz don Félix del Carpio - con su criado, Lope - y doña Ana, que tienen concertado su casamiento pero que tienen que esperar hasta que don Félix haga un viaje a Sevilla. Sin embargo, don Félix encuentra en Getafe a Inés, una bella villana con la que se había entretenido mientras ella visitaba la corte. En Getafe se detiene don Félix el tiempo suficiente para proseguir sus escarceos y prometerle matrimonio a Inés, pero al no poder gozarla, y temiendo que doña Ana le descubra, parte para Sevilla. El acto segundo se abre meses después, con la vuelta de don Félix y Lope a Madrid y la tristeza de Inés, que no ha tenido noticias de él. Al enterarse del regreso de su amado, Inés consigue entrar como sirvienta en casa de doña Ana. Allí percibe los preparativos de boda y, celosa, le solicita a amor "algún remedio» para «estorbar» el casamiento (vv. 1476-1481), lo que hará que «derroch[e] ingenio» durante el resto de la obra (Díez Borque 1999:33). Primeramente, engaña a don Félix simulando ser una sayaguesa que ha pasado por un trance amoroso muy familiar: un «hidalgote» fue a requebrarla y no la pudo gozar, pero la enamoró, por lo que ha venido a buscarle (vv. 1813-1856). Luego, la astuta villana escribe un anónimo que le entrega a doña Ana, confesando ser la autora del escrito en un aparte. El anónimo contiene una grave acusación contra la limpieza de sangre de don Félix:

La lástima que os tengo, señora doña Ana, me ha obligado a escribiros, que este caballero con quien os casáis es morisco, y ansimismo lo es su criado; ya se les hace la información para echallos de España. Su agüelo de don Félix se llamaba Zulema, y el de don Lope, lacayo, Arambel Muley, que eso del Carpio es fingido, porque con los dineros que ganó su padre a hacer melcochas en el Andalucía ha comprado la caballería con que os engaña (v. 2034Acot).

Este anónimo desencadena los episodios más hilarantes de la comedia. Los personajes creen la infamia y comienzan a verles cara de moro a Lope, primero, y luego al propio don Félix:

5 Aparte del trabajo de Márquez Villanueva [1988], que comentaremos abajo, solo conocemos tres estudios sobre La villana de Getafe, amén de la edición crítica de José María Díez Borque [1990]. En ellos, Victor Dixon [1988] examina el tema del coche y el mito de Faetón; Díez Borque [1999], el personaje de Inés; y José María Ruano de la Haza [2005], el del gracioso. 
DoÑa AnA

Que Lope morisco sea, aun lo parece en la cara; mas don Félix...

(vv. 2048-2050).

RAMÍREZ

De Lope siempre temía, Julia, que morisco era: cara tiene de quemado (vv. 2063-2065).

DoÑA ANA

Más de espacio le miré, no en balde la fama suena. Morisco me ha parecido, y aun en el hablar también (vv. 2085-2088).

URBANO Él tiene de moro el gesto, $\mathrm{y}$ aun lo parece en hablar (vv. 2093-2094).

Además, todos comienzan a insultarles con todos los tópicos antimoriscos del momento. Salen a relucir el oficio de buñolero y melcochero (vv. 2123-2130), el insulto de perro (vv. 2128; 2154-2155) ${ }^{6}$ y, por supuesto, la carne de cerdo y el idioma árabe:

$\begin{array}{ll}\text { RAMíReZ } & \begin{array}{l}\text { He de colgar un pernil } \\ \text { para que vayan huyendo } \\ \text { (vv. 2149-2150). }\end{array} \\ & \text { Si supiera algarabía } \\ & \text { hablara a vuesa merced, } \\ & \text { a quien suplico se vaya } \\ & \text { de Madrid, que estos hidalgos } \\ & \text { no van a caza con galgos } \\ & \text { (vv. 2178-2182). }\end{array}$

6 Véase, sobre su extensión, la cédula que promulgó Carlos V el 7 de diciembre de 1526 (Caro Baroja 1976:171). 
La vis comica de estos chistes tiene su correlato en las respuestas indignadas de Lope, que encarece su limpieza de sangre con ridículas hipérboles:

\author{
¡Hola, escudero! Yo he sido \\ el que el tocino inventó; \\ yo los puercos engendré, \\ mía la invención ha sido \\ (vv. 2156-2159). \\ Pues ¡vive Dios! que deciendo \\ de un estornudo del Cid \\ (vv. 2238-2239).
}

La jornada acaba con el duelo entre don Félix y un hidalgo que corteja a doña Ana y que, cree el ofendido galán, ha sido el responsable de la calumnia. Pero lo que realmente soluciona el problema es la noticia de que a don Félix le han concedido un hábito de caballero, lo que le sitúa fuera de sospecha en cuanto a limpieza de sangre. Sin embargo, esto no soluciona el enredo amoroso, pues, por despecho, don Félix abandona a doña Ana y trata de casarse con doña Elena. Esto exige un nuevo «remedio» (v. 2343) por parte de Inés, que se disfraza de hombre para enamorar a la dama y hacer que deje su pretensión, mediando unas escenas muy cómicas en las que doña Elena muestra su amor por Inés. El engaño funciona, con lo que el galán vuelve a brazos de doña Ana, lo que desencadena el tercer y último enredo de Inés. Esta vez, la villana finge haber recibido de unos parientes indianos cuarenta mil ducados de dote, lo que convence a don Félix para casarse con ella.

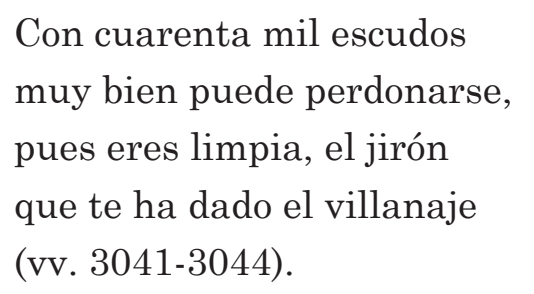

El pastel se descubre cuando el enlace ha sido ya efectuado, por lo que don Félix acaba celebrando su suerte por haber hallado «mujer de tan raro ingenio, / de tal hermosura y talle» (vv. 3421-3422). Se trata, pues, de una deliciosa comedia 
interesante por su traza, por sus obvias referencias a la figura del autor y por el contexto político que la crítica ha visto en la obra.

Exceptuando La villana de Getafe, casi todo el resto de nuestro corpus aparece analizado en el célebre trabajo de Orozco Díaz Lope y Góngora frente a frente [1973], en el que el erudito granadino pretendía arrojar luz sobre las respectivas personalidades de los dos grandes poetas áureos examinando su relación. La obra es un hito en los estudios de polémicas literarias del Siglo de Oro, pero adolece de la imprecisión de su punto de vista psicológico basado en nociones apriorísticas: Orozco parte de que Lope y Góngora son personalidades contrapuestas y dedica gran parte de su análisis a confirmar este particular con los textos de los dos autores. ${ }^{7}$ Esto no invalida la mayoría de las observaciones del erudito, y en especial de las que atañen a la polémica del romancero. A ella dedica los capítulos III y IV, mostrando que la batalla entre los dos ingenios esconde no solo un inevitable choque de personalidades opuestas, sino también una escaramuza entre identidades locales. Lo percibe en dos de los romances de nuestro corpus, «Ah, mis señores poetas!», que atribuye al cordobés «u otro andaluz motivado por él» [1973:48], y su respuesta «PPor qué, señores poetas?», que adjudica al madrileño [1973:53]. Del análisis de los textos Orozco [1973:59] concluye que

Uno y otro, como Anteo de su propia tierra, tomaban fuerzas de castellanismo y andalucismo que les impulsaban a medir sus armas en nuevos combates literarios. Así, el próximo encuentro romanceril será un choque de Castilla y Andalucía, o mejor dicho, un ataque del castellano al andaluz que se había burlado de Castilla. Y en ese ataque surgirán las primeras ofensas, que el caballero andaluz no olvidará.

Orozco anuncia que la escaramuza precede a otra mayor que tendría como casus belli el simbolismo del Tajo.

Se trata de los romances "A vos digo, señor Tajo», que Góngora habría escrito «en caliente» (Orozco Díaz 1973:61) en 1591, y de la respuesta lopesca «Bien parece,

7 Orozco se basa en los clásicos prejuicios sobre los dos poetas —Lope vital, Góngora reflexivo; Lope sanguíneo, Góngora melancólico-. En el caso del Fénix, estas ideas datan de su propia época y se consolidan durante el siglo xIx (Sánchez Jiménez 2006:4-5; 11-16); en el de Góngora nacen de una interpretación favorable de las denuncias de retorcimiento de la crítica decimonónica. A estos prejuicios Orozco añade otros basados en ideas sobre el carácter de las gentes: así, en su opinión Góngora ejemplifica el orgullo que supuestamente es propio del pueblo cordobés. 
padre Tajo». ${ }^{8}$ En la contienda, Orozco toma partido por Góngora, pues le parece que su sátira es juguetona y no ofende ad hominem a Lope (pese a la broma sobre los cornudos toledanos). Orozco explica la pulla acudiendo al carácter del cordobés, pues detecta en este y otros romances de Góngora «su orgullo de andaluz y su desprecio de Castilla» [1973:70], pero pese a ello considera que la respuesta de Lope fue desproporcionada. En su opinión «Bien parece, padre Tajo» sería un «oportunista ataque personal del madrileño, que se lo lanzó, sin motivo, cuando él [Góngora] solo le había dirigido hasta entonces burlas e ingeniosidades literarias» [1973:68]. Y es que Orozco vio en los siguientes versos una acusación del Fénix contra Góngora, en los que el madrileño tacharía al cordobés de morisco:

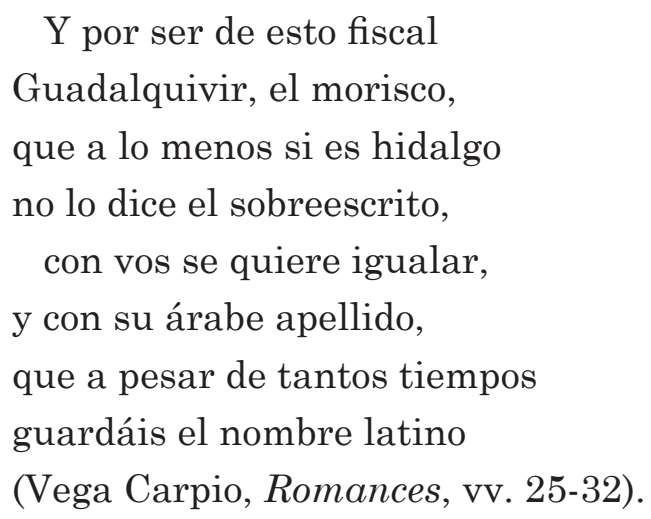

Sin embargo, una lectura cuidadosa revela que el «morisco» es aquí el Guadalquivir, y no el poeta, pese a que, claro, el río representa a su autor del mismo modo que el Tajo encarna a Lope y a los toledanos. No hay insidias contra «la limpieza de sangre del caballero andaluz», como supone Orozco [1973:68], ${ }^{9}$ pero sí un enfrentamiento de regiones - y, sobre todo, de grupos de poetas - asociados a los respectivos ríos, Guadalquivir y Tajo. ${ }^{10}$ No obstante esta interpretación, la hipótesis central de

8 La atribución a Lope data ya del Ramillete y fue aceptada por Millé y Giménez [1930:67-68], José F. Montesinos [1952:368], José María de Cossío [1960:423] y Orozco [1973:64-65]. Sigue sin discutirse (López Gutiérrez 2003:434; Madroñal Durán 2012:300).

9 Orozco no explica cómo Lope podría haberse enterado de que cuando en 1568 el tío de Góngora, don Francisco, pidió el expediente de limpieza para conseguir la ración, salió a la luz que había en la familia una rama judaizante. Según Orozco [1973:75], «Lope [...] se aprovechó de esos rumores y se lo lanzó bromeando, pero ofensivo, a don Luis».

10 Carreira documenta que así lo vieron los contemporáneos. Un manuscrito de la biblioteca de la University of Pennsylvania (Ms. Span 37) trae con el romance de Góngora lo siguiente: «Entiéndese que debajo de la metáfora del río Tajo se hizo contra Lope de Vega Carpio, insigne poeta castellano» (Carreira 1998:I, 547). El río representa al poeta y a su región de origen. 
Orozco sigue siendo válida: el romancero fue uno de los campos de enfrentamiento entre Lope y Góngora, y uno en el que ambos usaron como égida, en serio o en broma, el honor de sus respectivas regiones de origen, lanzando diversas pullas a la contraria.

Pese a la influencia de la monografía de Orozco en los estudios sobre Lope y Góngora, existe una línea de trabajos sobre las parodias y sátiras del romancero morisco que no la tiene en cuenta. Además, estos estudios parten de una hipótesis completamente distinta: los romances y sus respuestas contendrían ideas políticas polémicas sobre la posición de los moriscos en la comunidad nacional. De entre estos estudios hemos elegido por su representatividad los de Carrasco Urgoiti, Márquez Villanueva y Fuchs. ${ }^{11}$ Se basan en parte en el trabajo de Chantal Colonge [19691970:141], que contrastaba aquellos romances satíricos de tono más ameno con otros - la mayoría, dice la estudiosa francesa-cuyo cariz era mucho más agresivo:

Si quelques romances moriscos burlescos ont un ton assez neutre à l'égard des Morisques, d'autres —et c'est le plus grand nombre— manifestent pour eux un mépris non dissimulé. Tel est le thème essentiel de la plupart de ces romances.

Pese a esta generalización, las conclusiones de Colonge son bastante razonables. En primer lugar, acepta que acusaciones sobre limpieza de sangre como la de «Toquen apriesa a rebato» se hacían en broma [1969-1970:144], y en segundo lugar, que los argumentos patrioteros de las sátiras no provocaron la desaparición del romancero morisco. De ello hay que culpar más bien al cansancio estético (Colonge 19691970:147). Los trabajos de Carrasco Urgoiti [1986], Márquez Villanueva [1988] y Fuchs [2009] llevarán bastante más lejos la asociación entre política y romancero que dejó entrever Colonge.

Entre ellos, el de Carrasco Urgoiti resulta especialmente útil porque clasifica los elementos característicos de las sátiras..$^{12}$ Como señala esta reconocida experta

11 Hay un resumen del estado de la cuestión hasta el momento en Carreira [1998:I, 547]. Incluye las aportaciones de Juan Millé y Giménez [1933; 1930:175-177], que no hemos explicado pero que ven los romances satíricos y sus respuestas desde un punto de vista intermedio entre el de Orozco y el de Carrasco Urgoiti y compañía: los romances serían muestra del enfrentamiento entre dos personalidades, dos regiones y dos escuelas poéticas antagónicas. Una opinión posterior, pero dependiente de la de Carrasco Urgoiti y Márquez Villanueva, se encuentra en Manuel Ruiz Lagos [2001:14], para quien los romances moriscos encubren «un esfuerzo político por salvar los restos de la propia nación, perdidos en la aventura feroz de la contienda».

12 También se pueden encontrar en la monografía de Amelia García Valdecasas [1987:95-96]. 
en literatura morisca, ${ }^{13}$ los censores de los romances moriscos resaltan siempre el contraste entre «las estilizadas figuras de damas y caballeros moros» de los romances con «el segmento de la población coetánea constituido por los campesinos y artesanos moriscos», en una "superposición de efecto grotesco entre figuras literarias y sujetos de la realidad cotidiana» [1986:115]. A esto Carrasco Urgoiti añade otras características que ahora nos interesan menos: la "tendencia lacrimosa" de los romances y sus descripciones de fastuosos ropajes [1986:117; 136]. ${ }^{14}$ Además, y esto ya nos atañe directamente, Carrasco Urgoiti [1986:116] indica que bajo los ataques subyacía una grave intención política:

el mayor grado de hostilidad con que se ataca el romance morisco, en comparación, por ejemplo, con el pastoril hace pensar en estímulos de índole extraliteraria. Entre los móviles del vituperio pesa mucho, sin duda, la mala voluntad que anima a unos hombres de letras contra otros, especialmente la inquina contra Lope de Vega, pero la denuncia del romance morisco nuevo responde también frecuentemente a motivaciones de orden social o político.

Concretamente, Carrasco Urgoiti [1986:121] señala que a partir de 1593 los críticos comenzaron a preocuparse por la posible reacción de los lectores ante los romances moriscos, y a sugerir que los poetas que los cultivaban tenían «cierto grado de solidaridad» con los moriscos reales. Es lo que censurarían los romances más agresivos, como «Tanta Zaida y Adalifa» o «Ah, mis señores poetas!». Son poemas que según Carrasco Urgoiti [1986:122] van «más allá de las ideas convencionales en su tiempo, para hacer propaganda de la posición más intransigente, que como sabemos acabaría por imponerse», es decir, la antimorisca. Atacarían al romancero morisco «en nombre de los valores tradicionales y castizos, por considerar que da una falsa imagen de España» [1986:125], por lo que acabarían proponiendo temas más españoles. Esto convertiría los dichos romances satíricos en «piezas de propaganda anti-morisca que van preparando el terreno para la expulsión» [1986:132].

Tratando específicamente «iAh, mis señores poetas!», Carrasco Urgoiti reconoce que el romance tiene mucho de obra de academia [1986:125], pero entiende

13 Carrasco Urgoiti es autora de varios estudios sobre el tema, de los que bastará recordar $E l$ moro de Granada en la literatura [1989].

14 Cabe recordar que ninguna de estas características era exclusiva de los romances moriscos. Más bien eran comunes a todos los géneros idealizantes del momento: ni la literatura de caballerías, ni la ariostesca ni la pastoril es menos lacrimosa o dada a la sastrería poética. 
que bajo el poema y su réplica, «Por qué, señores poetas?» subyacen polémicas muy serias. En ello insiste al analizar este poema, que en su opinión «expone precisamente la opinión de que los españoles deben asumir el pasado musulmán como parte superada pero honrosa de su historia» y "plantea, sin duda dentro del tono de juego que impera en las academias poéticas, la reivindicación del pasado árabe, y de alguna fracción de su herencia cultural, cuya españolidad afirma», sosteniendo «el derecho del morisco a ser considerado español» [1986:132; 134].

Márquez Villanueva también toma en serio los comentarios antimoriscos tratando de contextualizar unas referencias de La villana de Getafe en el hipotético marco biográfico de unas injurias contra el Fénix. Se trata de los pasajes en los que a dos personajes cuyos nombres remiten al Fénix — don Félix del Carpio y su criado Lope (Ruano de la Haza 2005:115) — ${ }^{15}$ se les levanta que son de ascendencia morisca. Según Márquez Villanueva, se trata de una referencia juguetona a una acusación bastante seria que había surgido precisamente en los romances paródicos y satíricos arriba aludidos. Al respecto, el erudito sevillano relaciona los pasajes de La villana de Getafe en los que se les ve cara de moro a don Félix y a Lope con los versos de «Toquen apriesa a rebato» que acusaban al Fénix de tener aficiones y aire de morisco (Vega Carpio, Romances, vv. 113-124). Márquez Villanueva reconoce que el ataque de «Toquen apriesa a rebato» es "demasiado arbitrario e infundado», con "tono abiertamente chusco» [1988:317-318], para alarmar demasiado a Lope. Por ello, sostiene que lo único que hizo el madrileño ante el poema fue «correr (encubierto, como de costumbre) a la defensa específica del género morisco», con el romance «¿Por qué, señores poetas?» [1988:318]. Sin embargo, el estudioso explica que con el ascenso del duque de Lerma ser tildado de morisco pasó a ser una acusación grave. El ambiente había cambiado y las condiciones y opinión pública sobre los moriscos se endurecieron de tal modo que produjeron el fin del romancero morisco [1988:320-322]. ${ }^{16}$ Como «lo que comenzó en pura broma de los del oficio

15 Además, Alderete, que es el apellido de doña Ana, remite al de la primera mujer de Lope, Isabel de Urbina, que era de noble prosapia (Alonso Cortés 1927). Sobre estos aspectos biográficos, véase la edición de Díez Borque [1990:22], especialmente las notas a los vv. 1757-1759, 2181 y 2473.

16 La idea de que las condiciones políticas determinaron el éxito y el fracaso del romancero morisco es recurrente en la crítica. En cuanto a sus orígenes, Manuel Alvar [1974:129] y, en su estela, García Valdecasas [1987:15] y Manuel Ruiz Lagos [2001:9; 14], proponen que la rebelión de la Alpujarra fomentó el interés en la literatura morisca. Por lo que respecta a su decaer, ya Ramón Menéndez Pidal [1953:160-161] lo ligó al sentimiento antimorisco. Lo repite Márquez Villanueva [1988:322], para quien la desaparición del género es «de obvia naturaleza política y motivada por el endurecimiento de la línea oficial hacia los moriscos». 
amenazaba convertirse en algo muy serio» [1988:321], Lope habría decidido responder en La villana de Getafe a las acusaciones contra su sangre. La obra fue «escrita en 1613-1614, días de máximo furor anti-morisco», y en ella el Fénix abandonaría su defensa de los moriscos para sostener la importancia de la limpieza de sangre, así como su propia condición de cristiano viejo — el personaje de don Félix obtiene un hábito-. Según Márquez Villanueva, la comedia sería, pues, una defensa y una «despedida melancólica a unos viejos amigos, tan moros por la onomástica como castizos por la toponimia, y ahora tan desterrados de la poesía como del suelo de España los verdaderos moriscos» [1988:322].

Sin conocer el estudio de Márquez Villanueva, ${ }^{17}$ Fuchs sostiene una opinión semejante, al explorar cómo se asumió la presencia de la cultura andalusí en la construcción nacional española que se llevó a cabo tras 1492. Para mostrarlo, Fuchs trata el romancero morisco haciendo ver cómo la maurofilia literaria no es una simple moda sin conexiones con la realidad del momento [2009:72], como sugiere Georges Cirot [1938-1944]. Más bien, según ella el romancero morisco presenta una visión alternativa de la nación española que incluye la herencia andalusí, porque «although the ballads are not historical in their invocation of actual events, they necessarily reference the larger Spanish debates about the place of Moors and Moorish culture in Spain» [2009:74]. La posición de los romances moriscos en esos debates sería, necesariamente, favorable a la herencia andalusí, pues la identificarían con la cultura aristocrática, idea por otra parte compatible con la tradición y con muchos hábitos de la época [2009:75]. Fuchs no expone esta posición analizando los romances moriscos en sí, sino el debate entre los romances satíricos y su respuesta («¿Por qué, señores poetas?»). Y al respecto sostiene que los primeros muestran no solo «aesthetic ennui at the repetition of so much Moorish lore, but, more important, political outrage at the choice of topic» [2009:81]. Es decir, según Fuchs las sátiras destilan sentimiento antimorisco al denunciar que los romances traicionan la supuesta esencia hispánica — asociada con la cristiandad gótica - y al proponer otros héroes y géneros más decorosos que los moros granadinos. Y, lo que es más importante, para Fuchs estos ataques significan que la literatura morisca tenía connotaciones políticas, y que los autores de romances moriscos serían en algún grado maurófilos: «Góngora or Lope's choice of subject, as that of their contemporaries, is not unmotivated. (Clearly, the tremendous popularity of the first

17 Tampoco cita a Orozco [1973], ni a Millé Giménez [1930; 1933] o a García Valdecasas [1987]. 
poems immediately reinforces their maurophile tendencies)» [2009:76]. En opinión de Fuchs, la respuesta a estos romances maurófobos, «¿Por qué, señores poetas?», sería una muestra de la gravedad de la cuestión, así como una propuesta para construir un ideal nacional diferente que valorizara el pasado moro. ${ }^{18}$

En suma, según Carrasco Urgoiti, Márquez Villanueva y Fuchs, los romances moriscos destilarían una maurofilia nada inocente en el contexto de una época en la que se trataba de la posición de los moriscos en el territorio y en la construcción imaginaria de la nación. Los autores de estos romances serían políticamente maurófilos, y eso habría despertado las iras de los poetas maurófobos - los autores de las sátiras-, que representarían la posición más intransigente, la que triunfó con los decretos de expulsión de 1609 y 1610. De hecho, sostienen estos críticos, el romancero morisco habría desaparecido de los florilegios precisamente por estas razones políticas, pues en el contexto de la época los Muzas y Gazules de los romances se identificaban con una peligrosa posición a favor de los moriscos. En esta polémica política, Lope, como destacado creador del subgénero del romance morisco, habría tenido una posición claramente maurófila. Luego, según Márquez Villanueva, habría sufrido ataques por ello que le habrían llevado a retractarse en La villana de Getafe.

Como el lector habrá podido intuir, semejantes ideas nos resultan hiperbólicas y un tanto alejadas del texto de los poemas. En general, los argumentos de estos críticos adolecen en primer lugar de un problema de corpus: ${ }^{19}$ tratan de demostrar que los romances moriscos eran políticamente maurófilos basándose en el testimonio de unos pocos romances satíricos. Lo cierto es que las sátiras solamente muestran que algunos autores les reprocharon a los romances moriscos su temática islámica, y que esto ocurrió en unos contextos que desconocemos, pero que parecen

18 Fuchs [2009:86] lo expone contrastando las protestas del poema con la de Núñez Muley ante la Audiencia Real de Granada en 1567. Su defensa de la hispanidad de Granada y la cultura morisca ante los decretos filipinos recuerda la del poeta al sostener que Granada y Muza son tan españoles como Toledo y don Rodrigo.

19 Además apreciamos algunos errores puntuales en el trabajo de Fuchs. En primer lugar, la estudiosa entiende equivocadamente que las referencias al exilio de «Háganme vuestras mercedes» apuntan a la (futura) expulsión de los moriscos [2009:76], y no al destierro del propio Lope en 1588, lo que la conduce a una interpretación excesiva sobre la posición del poeta ante el problema morisco [2009:78]. En segundo lugar, no se da cuenta de que el «ninfo de Leteo» de «iAh, mis señores poetas!» alude a un poeta andaluz (por el río Guadalete, en un juego de palabras bastante común), posiblemente Góngora. Al no ver la referencia, acude a las connotaciones clásicas del río del infierno para caer en una lectura desviada [2009:85]. 
de academia literaria. A su vez, para demostrar que los romances satíricos presentaban acusaciones políticas sumamente serias, los estudiosos acuden a un solo romance, «¿Por qué, señores poetas?». Este único texto debería probar que en este escarceo poético se ventilaban cuestiones de identidad nacional, y no solo de estética.

Sin embargo, unos pocos romances satíricos un tanto agresivos ${ }^{20}$ y el único poema que les responde no bastan para demostrar semejante hipótesis, y sí quizás para sugerirla. A la vista de los datos, y si no consideramos que se trata de bromas de academia, solo podemos sostener que algunos escritores entendieron que había un subtexto político bajo los romances moriscos. Y que parece que un autor anónimo — quizás Lope, pero no se puede demostrar - respondió en el mismo tono en «¿Por qué, señores poetas?». Todo eso, de nuevo, si interpretamos que el registro de la escaramuza es serio, y no de duelo académico.

Por lo que respecta al argumento de que las tensiones políticas acabaron con el género, resulta simplemente insostenible. La propia Carrasco Urgoiti proporciona los datos para refutarlo, pues en su estudio de la comedia morisca demuestra que este subgénero abunda en la producción del Fénix. Está presente en su fase temprana, pero también lo encontramos bastante después. Y es que en los diez años siguientes a 1604 Lope «sigue refundiendo o aumentando el repertorio morisco-granadino que al parecer cierra La envidia de la nobleza, compuesta en 1613 o más tarde, pero en ningún caso después de 1618» (Carrasco Urgoiti 1982:52). Es decir, cuando los romances moriscos pasaron de moda la comedia morisca seguía representándose, y continuaría escribiéndose durante toda la época de manía antimorisca y durante los años de la expulsión, e incluso después. Este dato debilita la tesis de que los romances moriscos tenían subtexto político: las comedias moriscas no recibieron crítica alguna del tipo «iAh, mis señores poetas!», ${ }^{21}$ aunque trataban los mismos temas e incluso a veces con los mismos personajes. Ante este contraste solo cabe entender literalmente lo que expresan los autores de las sátiras: que están cansados de que todos los romances sean de moros, y que proponen cantar otros temas. Y podemos interpretar que nunca hubo tales quejas contra la comedia morisca porque los moros no dominaron las tablas como los romanceros: en los corrales los Muzas y Gazules ya compartían cartel con el Cid, don Rodrigo y compañía. Además,

20 El lector habrá notado el énfasis de Márquez Villanueva y Fuchs en «iAh, mis señores poetas!».

21 No tiene sentido pensar que los detractores de los moriscos consideraban que el teatro era inofensivo, y que lo que había que corregir era la difusión de romances: más bien, ante obras de contenido político la atención de los moralistas se ocupa siempre más del teatro que de la poesía. 
la popularidad de las comedias moriscas también afecta a la tesis de Márquez Villanueva sobre Lope y las infamias a su prosapia: si el Fénix comenzó en época de Lerma a tomar en serio y temer la acusación de morisco, no tiene sentido que les recordara a sus lectores sus comedias moriscas en el Peregrino, ni, por supuesto, que siguiera escribiéndolas hasta los años de La envidia de la nobleza.

Tampoco resulta coherente la posición de Lope en esta supuesta polémica político-literaria. Para Fuchs —e, implícitamente, para Carrasco Urgoiti—, el Fénix sería pro-andalusí por haber escrito romances moriscos y, posiblemente, «¿Por qué, señores poetas?». Sin embargo, para Márquez Villanueva Lope habría pasado de simpatizar — tibiamente - con los moros a enarbolar una oportuna maurofobia y un casticismo goticista con el cambio de aires políticos, tras la llegada de Lerma al poder. Son hipótesis contradictorias, a no ser que entendamos que Carrasco Urgoiti y Fuchs solo recogen una etapa de la evolución política de Lope, y Márquez Villanueva, dos. En todo caso, son conclusiones incompletas, pues no tienen en cuenta el resto de la producción del autor. Valga el ejemplo de «La desdicha por la honra", una de las Novelas a Marcia Leonarda. Ninguno de estos estudiosos citados le presta atención, pese a que la novelita de La Circe (1624) presenta un notable juego de identidad alrededor del tema de los moriscos y la limpieza de sangre, y pese a que la crítica ha estudiado el particular (Bataillon 1947; Checa 2001; Redondo 2000). ${ }^{22}$ No es el momento de resumir ni estos estudios ni la novela, pero baste señalar que sería difícil emplearla para argüir que Lope era maurófobo.

Asimismo queda fuera de los estudios de estos tres críticos el romance «Bien parece, padre Tajo», pese a tocar tanto el tema morisco como la posible opinión política de Lope al respecto. ${ }^{23}$ Como indicamos al tratar del libro de Orozco, el romance responde a uno de Góngora "A vos digo, señor Tajo» en lo que Cossío denominó una «polémica fluvial» [1960:423]. Góngora había producido «un gracioso vejamen al río toledano» con conceptos «ingeniosos y llenos de gracia poética» (Cossío 1960:424). En respuesta, Lope, cuya relación con Toledo era estrecha, «toma a su cargo la defensa del celebrado río, y, lo que es más grave, la acusación al Guadalquivir, y puede decirse que a lo andaluz» (Cossío 1960:424). Como vimos arriba, parte de esta defensa consistió en contrastar la limpieza de sangre del gótico Tajo con la

22 Augustin Redondo [1999] también ha estudiado el tema moruno en otra de las Novelas a Marcia Leonarda, «Guzmán el Bravo».

23 Lo examinó Orozco [1973], y luego Cossío [1960]. 
dudosa prosapia moruna de «Guadalquivir, el morisco» (v. 26). Si consideramos que este texto tiene implicaciones políticas antimoriscas, como sin duda habrían hecho Carrasco Urgoiti y Fuchs, el ataque colocaría a Lope de lleno en el campo maurófobo. De haberlo recordado, Márquez Villanueva se habría apresurado a incluir el romance entre sus argumentos para construir la temible figura del Lope inquisitorial y casticista que pintó en sus estudios sobre el Fénix. Sin embargo, «Bien parece, padre Tajo» es anterior a 1593, por lo que desmontaría las teorías del erudito sevillano, que no podría seguir sosteniendo que Lope se hizo maurófobo a partir de la llegada de Lerma al poder. Es más, el texto es casi contemporáneo de «¿Por qué, señores poetas?», que apareció impreso en 1592 y que sería el gran ejemplo — supuestamente lopesco - de la defensa del romancero morisco y de la herencia andalusí. Por tanto, tenemos el incómodo hecho de que Lope apoyaría a los moriscos en un romance y los denostaría en otro al año siguiente. Las contradicciones nos exigen buscar otra explicación, también aplicable a La villana de Getafe. De hecho, esta comedia nos servirá de campo de experimentación antes de extender nuestra hipótesis a los romances de la polémica morisca y fluvial.

El gran problema de la interpretación de Márquez Villanueva para La villana de Getafe es que se opone al decoro genérico: el estudioso supone que Lope usa el marco de una comedia ligera para ventilar cuestiones de naturaleza muy seria y cuasi trágica, como son una acusación real de sangre manchada y el problema morisco. Sin embargo, en la obra la infamia que idea Inés sirve más bien para desencadenar la risa que la reflexión sobre la suerte de los infortunados moriscos. Es más, recordaremos que la burla morisca es solo una de las que traza Inés durante la comedia, pues los atribulados don Félix y Lope también tienen que sufrir las consecuencias de su disfraz de indiano o de la ficticia dote de cuarenta mil ducados, que les dejan en el más solemne ridículo. La vis comica surge de estas situaciones y de los chistes arriba citados, y otros por el estilo, amén de la reacción de sorpresa e indefensión de don Félix, incapaz de contrarrestar el ingenio de Inés en los dos últimos actos de la obra. Inés llega incluso a llamar "pollino» y «jumento» a don Félix en varias ocasiones, sin que nadie parezca notarlo (II, vv. 286-288). Es decir, estamos claramente en una comedia ligera, y el objeto de la befa general es meridiano: los espectadores se identifican con Inés y se ríen de don Félix y su criado, no porque sean personajes negativos, sino porque sufren las burlas de la villana. Por tanto, si el Fénix se identifica con ellos, como demuestran mil detalles a lo largo de la obra, tenemos que concluir que en La villana de Getafe 
Lope se está riendo de sí mismo. Sin duda, el público reconocería las clarísimas pistas que unían al autor con sus dos personajes, no la menor de las cuales era la relación de don Félix con el tío del poeta, el inquisidor don Miguel del Carpio:24

Lope $\quad$ ¿No eres tú Carpio, sobrino
del famoso don Miguel
del Carpio, que hoy cuentan dél
un valor casi divino?
(vv. 1757-1760).

Impulsados por los nombres de Félix, Carpio y Lope, por la mención de los Alderete y de Elena, los espectadores se darían cuenta de que el autor de La villana de Getafe les estaba haciendo un guiño especial. Las referencias biográficas multiplican el potencial cómico de la obra, invitando al público a reírse no solo de algunos personajes, sino también del propio poeta. No es un recurso excepcional en el autor de las Rimas de Tomé de Burguillos, ${ }^{25}$ pero la crítica no ha sabido ver la ironía que casi siempre emplea Lope al tratar de sí mismo, y esto ha llevado a una interpretación demasiado grave de La villana de Getafe. Es claramente una lectura errada, pues la función central de las referencias a los moriscos es cómica, y concretamente autoparódica. No hay rastro de la apasionada defensa de los estatutos de limpieza de sangre que ve Márquez Villanueva, ni siquiera del alegato "pro sanguine suo» que propone el erudito [1988:307].

Tal intento nos parece incompatible con el tono de la obra, amén de que las fechas de la comedia tampoco habrían sido las más apropiadas para semejante apología: ¿por qué recordar, en 1613-1618, una supuesta acusación que databa de comienzos de los años noventa del siglo anterior? Ni estábamos ya en la época del furor antimorisco ni, por supuesto, en los comienzos del cambio de corriente, que habrían sido las situaciones más propicias para llevar a cabo la supuesta apología. La hipótesis no se sostiene, y tampoco nos parece verosímil que tras las bromas haya un intento de reflexionar sobre la cuestión morisca, pues el morisco no es

24 Lope alude a este personaje en la carta echadiza a Góngora (Epistolario, III, p. 314). También afirma haber vivido un tiempo en su casa durante su niñez en la dedicatoria de La hermosa Ester (Case 1975:129). Sobre este inquisidor tenemos estudios de Juan Millé y Giménez [1923] y Ricardo Espinosa Maeso [1978].

25 En ellas encontramos, por cierto, otro comentario sobre la facha moruna del poeta, en el soneto 68: «Si habéis visto al Sofí sin caperuza» (p. 233). 
precisamente el problema social que le interesa al Fénix en la obra. Como muchas comedias de Lope, La villana de Getafe contiene elementos satíricos y reflexiones sobre la sociedad del momento, pero son explícitas y bastante habituales, casi tópicas. Así, encontramos pullas sobre las muchas obras que hay en los edificios de la corte, comentarios contra el exceso de productos suntuarios (coches, ricas telas), contra las rebuscadas muestras de cortesía, e incluso sobre el poder del dinero (vv. 2400-2409). Tan solo tiene cierta relación con el tema morisco la crítica del vicio de hablar mal del prójimo, cuestión que tratan don Félix y Lope tras haber derrotado la calumnia sobre su supuesta sangre morisca:

$\begin{array}{ll}\text { Don Félix } & \begin{array}{l}\text { ¿Que haya lenguas en el mundo } \\ \text { que un testimonio levanten? }\end{array} \\ & {[\ldots]} \\ & \text { ¿No se puede remediar? } \\ \text { Lope } & \text { Es oficio de demonios. } \\ & {[\ldots]} \\ \text { Don FéLIX } & \text { Son lenguas impertinentes, } \\ & \text { y son vidas siempre ociosas. } \\ & \text { No hay ley más santa en la tierra } \\ & \text { que castigar los ociosos } \\ & (\text { vv. 2428-2457). }\end{array}$

Es decir, Lope critica la difamación en general, que es, como ha reconocido Márquez Villanueva [1988:305-306], uno de los blancos de La villana de Getafe. Pero no podemos llevar el mensaje político de la obra más allá de estas ligeras y muy poco específicas sátiras. Los ominosos tonos que percibe Márquez Villanueva contradicen el espíritu de la comedia, y no podemos buscarlos sin transformarla en una obra muy diversa.

La cuestión de la batalla sobre el romancero morisco resulta semejante. No podemos demostrar que las sátiras y contrasátiras salieran de sesiones de vejamen de una academia, pero el tono lo sugiere, como percibiera Carrasco Urgoiti [1986:125]. Las referencias apolíneas que notamos arriba, así como el hecho de que los autores parezcan conocerse, indica que estos romances ventilan diferencias poéticas, y solo secundariamente políticas. Por tanto, sean enfrentamientos reales, sean de justas de academia, los romances usan insultos políticos para ridiculizar al 
rival, para hacer reír, como en La villana de Getafe, en la que la calumnia sobre la sangre morisca constituía el mecanismo cómico central del segundo acto y parte del tercero. Como afirmó Márquez Villanueva [1988:317], el tono de estos romances es «abiertamente chusco», solo que, a diferencia del erudito sevillano, no creemos que estas bromas cobraran un sentido serio con el cambio de política en relación al problema morisco. Simplemente, somos testigos de que los poetas que se enfrentan a un rival del gremio ceban su artillería con lo que haga falta. Ello les lleva a adoptar posiciones que no son políticas - filomoriscas o maurófobas-, o al menos no lo son fuera de la polémica literaria en la que se emplean, y que desde luego no tienen por qué corresponder con la ideología política del escritor.

Los dos romances del Tajo ilustran este mecanismo y sirven para iluminar la polémica del romancero morisco. Si las atribuciones son correctas, presentan a un poeta andaluz, Góngora, atacando un río castellano, el Tajo, que sirve de metáfora de los ingenios toledanos, a los que trata de cornudos. La respuesta la proporciona un poeta madrileño / toledano (Madroñal Durán, 2012), Lope, que ataca al Guadalquivir, metáfora de los ingenios de Andalucía, a los que tacha de moriscos y de tener damas feas y sucias. Si pensamos que los romances reflexionan sobre la cuestión morisca, también habría que sostener que ventilan la triste situación de los cornudos o de las damas feas, algo patentemente absurdo. Lo más razonable es entender que el Fénix percibió el romance gongorino como lo que era, como un desafío poético. Y que lo aceptó, liderando así a todos los ingenios toledanos y aderezando su respuesta con las armas que estaban a su disposición, incluyendo las relativas a la limpieza de sangre. Algo muy semejante puede afirmarse sobre el caso de «¿Por qué, señores poetas?»: su autor, quizás Lope, adoptó la posición contraria porque asumió la bandera de los autores de romances moriscos contra el «ninfo del Leteo» que les atacaba. Es decir, las referencias a los moriscos eran un arma más en el arsenal poético del momento: los poetas podían esgrimirla a favor o en contra de los moriscos según la posición que adoptaran en el campo literario. Como en esas contiendas lo que se dirimía era quién era mejor pluma y más ingenioso, el contenido del chiste podía importar poco, pues solo estaba parcialmente determinado por el origen geográfico o la supuesta ideología del autor. El caso de Lope y los moriscos es una prueba determinante: primero el Fénix compone romances moriscos, luego los defiende mientras acusa a Góngora y a todos los poetas andaluces de ser moriscos, al poco exalta la limpieza de sangre del campesinado castellano en el Isidro, 
y posteriormente trata el tema de modo cómico en La villana de Getafe, y de modo irónico en «La desdicha por la honra». Por si fuera poco, al final de su carrera, en el acto II, escena V de La Dorotea, el Fénix parece defender los romances moriscos - y por tanto a los moros, dirían Carrasco Urgoiti, Márquez Villanueva y Fuchs - frente a los pastoriles (p. 140). Las contradicciones son notables. Tratar de determinar como Márquez Villanueva la ideología de Lope basándose en tal laberinto resulta imposible. Es más, podría considerarse incluso ingenuo, pues al fin y al cabo lo que nos presenta el Fénix es literatura, y no tratados políticos. La polémica sobre el romancero morisco se puede analizar, por tanto, literariamente, como deberíamos estudiar las que tocaron la literatura pastoril o ariostesca. ${ }^{26}$ Para hacerlo, debemos tratar de explicar por qué Lope se sitúa aquí o allá, y con quién y contra quién se coloca, alimentando su artillería con la posición política que haga falta. La literatura, y no la política, es la que revela la coherencia de estos movimientos, pues hacerse el promorisco o el antimorisco dependía de la situación literaria. Estamos ante un caso de estrategia autorial, y no de alta política, y parece ocioso señalar que leer así el romancero no supone «trivializarlo» (Fuchs 2009:8), sino recuperar su contexto literario.

En lo que concierne a los romances moriscos de Lope, la clave para entender estos movimientos la proporciona el estudio de Fuchs. Ella demuestra que durante la Edad Media e incluso el Siglo de Oro los españoles asociaron numerosos elementos de la cultura andalusí con lo distinguido y aristocrático [2009:75]. Las marlotas, jacerinas y sedas de los moros del romancero evocaban un ambiente elevado y superior en el que Lope quería colocar su mundo sentimental. La mezcla de esta tradición con la sensibilidad ariostesca y sus moros, ${ }^{27}$ que los estudiosos citados no han tenido en cuenta, explica el amor del Fénix por el género. Cuando pasó esta moda literaria en el contexto romanceril — se siguió cultivando la comedia morisca-, Lope adoptó otra convención que también evocaba un ambiente refinado y aristocrático, la pastoril. Ni pretendía con los romances de Gazul afirmar el papel de los moros en la historia de España, ni con los de Belardo reivindicar la posición

26 La bibliografía sobre la controversia acerca de la verosimilitud pastoril se puede encontrar resumida en la obra de Marcelino Menéndez Pelayo [1962:185] y Francisco López Estrada [1974]. Por lo que respecta a la poesía ariostesca, también tuvo sus detractores, como cualquier otra moda literaria (Lasso de la Vega 1942:núm. 12).

27 Véase la introducción y textos del romancero ariostesco de Maxime Chevalier [1968]. No obstante, la influencia de Ariosto en el romancero lopesco está por estudiar. 
del campesinado español: simplemente quería crear un trasfondo propicio para su construcción sentimental y asociarse a mundos que le aportaran prestigio literario y social. En el caso de sus romances y de La villana de Getafe, los objetivos de Lope eran literarios, no políticos, por triste que fuera la situación de los moriscos españoles y por importante que fuera el cambio de identidad nacional que se vivía en el momento (Fuchs 2009:10; Milhou 1985). Sus otras defensas o ataques a los moriscos responden a una lógica semejante, es decir, a quién se quiere enfrentar y por qué, pero detallar todos estos movimientos se saldría del propósito central de nuestro artículo. 


\section{BIBLIOGRAFÍA}

Alonso Cortés, Narciso, «Doña Isabel de Urbina, primera mujer de Lope de Vega»,

Boletín de la Real Academia Española, XIV (1927), pp. 674-678.

Alvar, Manuel, El romancero: tradicionalidad y pervivencia, Planeta, Barcelona, 1974.

BATAILlon, Marcel, «La desdicha por la honra: génesis y sentido de una novela de

Lope», Nueva Revista de Filología Hispánica, I (1947), pp. 13-42.

Caro Baroja, Julio, Los moriscos del reino de Granada, Istmo, Madrid, 1976.

Carrasco Urgoiti, María Soledad, «Notas sobre el romance morisco y la comedia de

Lope de Vega», Revista de Filología Española, LXII (1982), pp. 51-76.

Carrasco Urgoiti, María Soledad, «Vituperio y parodia del romance morisco en el romancero nuevo», en Culturas populares: diferencias, divergencias, conflictos: actas del coloquio celebrado en la Casa de Velázquez, los días 30 de noviembre y 1-2 de diciembre de 1983, ed. Y.-R. Fonquerme y A. Esteban, Universidad Complutense, Madrid, 1986, pp. 115-137.

Carrasco Urgoiti, María Soledad, El moro de Granada en la literatura: del siglo XV al XIX, Universidad de Granada, Granada, 1989.

Carreira, Antonio, ed., Luis de Góngora y Argote, Romances.

Case, Thomas E., Las dedicatorias de partes XIII-XX de Lope de Vega, Castalia, Valencia, 1975.

CHEcA, Jorge, «Lope de Vega ante la cuestión morisca: ideología y juego literario en La desdicha por la honra», Anuario Lope de Vega, VII (2001), pp. 7-24.

Chevalier, Maxime, Los temas ariostescos en el romancero y la poesía española del Siglo de Oro, Castalia, Madrid, 1968.

Cirot, Georges, «La maurophilie littéraire en Espagne au xvième siècle», Bulletin Hispanique, XL (1938), pp. 150-157, 281-296, 433-447; XLI (1939), pp. 6568, pp. 345-451; XLII (1940), pp. 213-227; XLIII (1941), pp. 265-289; XLIV (1942), pp. 96-102; XLVI (1944), pp. 5-25.

Colonge, Chantal, «Reflets littéraires de la question morisque entre la guerre des Alpujarras et l'expulsion (1571-1610)», Boletín de la Real Academia de Buenas Letras de Barcelona, XXXIII (1969-1970), pp. 137-243.

Cossío, José María de, «Notas a romances», en Studia philologica. Homenaje ofrecido a Dámaso Alonso por sus amigos y discípulos con ocasión de su 60 aniversario, ed. D. Alonso, Gredos, Madrid, 1960, vol. I, pp. 413-429. 
Cuarta y quinta parte de flor de romances, Alonso y Esteban Rodríguez, Burgos, 1592.

Díez Borque, José María, ed., Lope de Vega Carpio La villana de Getafe.

Díez Borque, José María. «Dos "villanas” para las tablas: Inés (La villana de Getafe)

y doña María (La moza del cántaro)», Cuadernos de Teatro Clásico, XI (1999), pp. 31-51.

Dixon, Victor, «Lope's La villana de Getafe and the Myth of Phaeton; or, the Coche as Status-Symbol», en What's Past is Prologue: A Collection of Essays in Honour of L. J. Woodward, eds. S. Bacarisse, B. Bentley, M. Claraso y D. Gifford, Scottish Academy Press, Edimburgo, 1984, pp. 33-45.

DuRÁn, Agustín, ed. Romancero de romances moriscos, León Amarita, Madrid, 1828.

DuRÁn, Agustín, ed., Romancero general, Rivadeneyra, Madrid, 1849, vol. I.

Espinosa Maeso, Ricardo, "Don Miguel del Carpio, tío de Lope de Vega», Boletín de la Real Academia Española, LVIII (1978), pp. 295-371.

Fuchs, Barbara, Exotic Nation. Maurophilia and the Construction of Early Modern Spain, University of Pennsylvania Press, Filadelfia, 2009.

García Valdecasas, Amelia, El género morisco en las fuentes del Romancero general, UNED, Valencia, 1987.

Góngora y Argote, Luis de, Romances, ed. A. Carreira, Quaderns Crema, Barcelona, 1998, 4 vols.

Góngora y Argote, Luis de, Romances, ed. A. Carreño, Cátedra, Madrid, 2000.

Lasso de la Vega, Gabriel, Manojuelo de romances, ed. E. Mele y Á. González Palencia, Saeta, Madrid, 1942.

López EstRada, Francisco, Los libros de pastores en la literatura española. La órbita previa, Gredos, Madrid, 1974.

LóPez GutiéRRez, Luciano, "Quevedo contra el perro de los ingenios de Castilla», La Perinola, VII (2003), pp. 427-437.

Madroñal Durán, Abraham, «Entre Cervantes y Lope: Toledo hacia 1604», eHumanista / Cervantes, I (2012), pp. 300-332.

Márquez Villanueva, Francisco, Lope: vida y valores, Universidad de Puerto Rico, Río Piedras, 1988.

Menéndez Pelayo, Marcelino, «La novela pastoril», en Orígenes de la novela, Consejo Superior de Investigaciones Científicas, Madrid, 1962, vol. II, pp. 185-346.

Menéndez Pidal, Ramón, Romancero hispánico (hispano-portugués, americano y sefardi), Espasa-Calpe, Madrid, 1953, vol. II. 
Milhou, Alain, «Desemitización y europeización en la cultura española desde la época de los Reyes Católicos hasta la expulsión de los moriscos», Manuscrits, I (1985), pp. 33-60.

Millé y Giménez, Juan, «Don Miguel del Carpio, tío de Lope de Vega», Nosotros, CLXXII (1923), pp. 3-10.

Mildé y Giménez, Juan, Sobre la génesis del Quijote: Cervantes, Lope, Góngora, el Romancero General, el "Entremés de los romances», etc., Araluce, Barcelona, 1930.

Millé y Giménez, Juan, «Miscelánea lopista», Revista de la Biblioteca, Archivo y Museo del Ayuntamiento de Madrid, X (1933), pp. 241-248.

Montesinos, José F., "Algunas notas sobre el romancero Ramillete de flores», Nueva Revista de Filología Hispánica, VI (1952), pp. 352-378.

Orozco DíAz, Emilio, Lope y Góngora frente a frente, Gredos, Madrid, 1973.

Ramillete de flores. Cuarta, quinta y sexta parte de flor de romances nuevos, Pedro Flores / Antonio Álvarez, Lisboa, 1593.

REDONDO, Augustin, «Du contexte historique au jeu narratif dans une nouvelle de Lope de Vega: Guzmán el Bravo (1624)», Langues Néo-latines, CCCX (1999), pp. 43-57.

REDONDo, Augustin, «La desdicha por la honra: de la concepción lúdica de la novela a la transgresión ideológica", en "Otro Lope no ha de haber". Atti del Convegno Internazionale su Lope de Vega. 10-13 febbraio 1999, ed. M. G. Profeti, Alinea, Florencia, 2000, vol. I, pp. 159-173.

Romancero general, Luis Sánchez / Miguel Martínez, Madrid, 1600.

Ruano de la HazA, José María, «Un gracioso en busca de un actor: La villana de

Getafe de Lope de Vega», en La construcción de un personaje: el gracioso, ed.

L. García Lorenzo, Fundamentos, Madrid, 2005, pp. 111-122.

Ruiz Lagos, Manuel, ed., Moriscos. De los romances del gozo al exilio, Guadalmena, Alcalá de Guadaíra, 2001.

SÁnchez Jiménez, Antonio, Lope pintado por sí mismo. Mito e imagen del autor en la poesía de Lope de Vega Carpio, Tamesis, Londres, 2006.

SÁnchez Jiménez, Antonio [en prensa]: véase Vega Carpio, Lope de, Romances.

Séptima parte de flor de varios romances nuevos, viuda de Alonso Gómez, Madrid, 1595.

Sexta parte de flor de romances nuevos, Pedro Flores, Lisboa, 1593.

Vega Carpio, Lope de, La Circe, con otras rimas y prosas, en Lope de Vega. Poesía, $I V$, ed. A. Carreño, Biblioteca Castro, Madrid, 2003, pp. 351-747. 
Vega Carpio, Lope de, La Dorotea, ed. D. McGrady, Real Academia Española, Madrid, 2011.

Vega Carpio, Lope de, Epistolario de Lope de Vega Carpio, ed. A. González de Amezúa, Real Academia Española, Madrid, 1935-1943, 4 vols.

VEGa Carpio, Lope de, Isidro, 1599, ed. A. Sánchez Jiménez, Cátedra, Madrid, 2010.

Vega CARPIO, Lope de, Novelas a Marcia Leonarda, ed. A. Carreño, Cátedra, Madrid, 2002.

Vega Carpio, Lope de, El peregrino en su patria, ed. J. B. Avalle-Arce, Castalia, Madrid, 1973.

Vega CARPIo, Lope de, Rimas humanas y divinas del licenciado Tomé de Burguillos y La Gatomaquia, ed. A. Carreño, Almar, Salamanca, 2002.

Vega Carpio, Lope de, Romances, ed. A. Sánchez Jiménez, Cátedra, Madrid, en prensa.

Vega Carpio, Lope de, La villana de Getafe, ed. J. M. Díez Borque, Espasa Calpe, Madrid, 1990. 